\title{
The Relationship Between Creativity and Social Intelligence in Students of Allameh Tabatabai and Shahid Beheshti Universities
}

\author{
Haji Agha Nejad. $Y^{1 *}$ \\ Zareh Neyestanak. M 2 \\ Dadashi. $\mathrm{M}^{3}$ \\ 1- ( ${ }^{*}$ Corresponding Author) \\ Ph.D. Student of Psychology, \\ Instructor, Imam Ali University, \\ Tehran, Iran. \\ Email: yaser.haji62@gmail.com \\ 2- Psychology, Ph.D. in Assistant \\ Professor, Azad University of \\ Nain, Azad University, Nain \\ Branch, Nain, Iran. \\ 3- Ph.D. Student of Psychology, \\ Instructor, Imam Ali University, \\ Tehran, Iran.
}

\begin{abstract}
Introduction: Intelligence is one of the factors affecting students and their progress. In this regard, the attention to the nature of intelligence, especially social intelligence, how to crystallize wise behaviors, assessment methods, measurements of intelligence and interpersonal and interpersonal differences have long been of interest to everybody. Since the beginning of the 20th century, studies on the nature of intelligence and intelligence capacity in children, adolescents and adults, and using various tools to evaluate the level of intelligence in different countries had been considered in many countries
\end{abstract}

Objective: The aim of this study was to determine the relationship between creativity and social intelligence among students of Allameh Tabatabai University and Shahid Beheshti University.

Material and Methods: The statistical population of this study was all students of Psychology and Education Faculty of studied universities of whom 300 people were selected using random sampling based on Morgan's table. The measurement tools used in this research are the standard Randsip's Creativity Questionnaire and the Kerry's Social Intelligence Standard Questionnaire. Data analysis was done using independent t-test, analysis of variance, Pearson correlation, multiple linear regression.

Results: The results showed that there was no significant difference between the components of creativity and social intelligence and the results of analysis of variance showed that there was a difference between the average creativity of students based on the educational levels and also some components of social intelligence components such as social information processing, social skills and social awareness predict creativity significantly.

Discussion and Conclusion: According to the results of this study, it can be concluded that the components of social intelligence play an important role in creating and stimulating creativity in students. It also seems that the university can play an important role in students' scientific and professional future by improving their motivation and academic spirit

Keywords: Creativity, Social Awareness Social Intelligence, Social Information Processing, Social Skills. 


\section{رابطه خلاقيت و هوش اجتماعى در دانشجويان دانشكاههاى علامه طباطبايى و شهيد بهشتى}

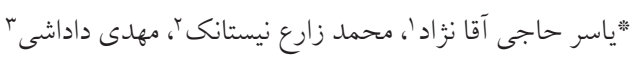

جكيده

مقدمه: يكى از عوامل تأثير كزار بر دانشجويان و ييشرفت آنها عامل هوش است. در اين رهكَر توجه به ماهيت هوش

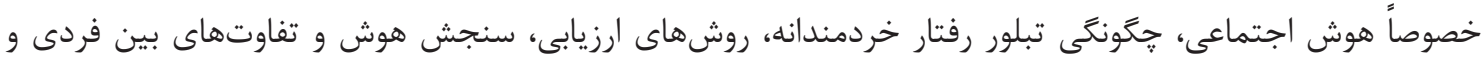

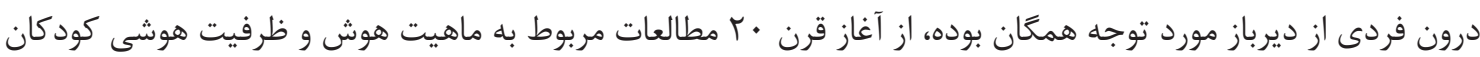

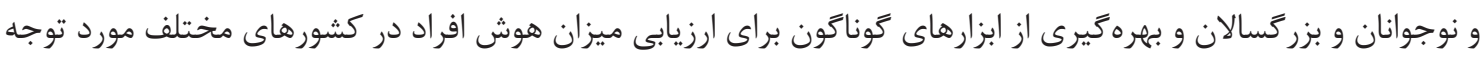

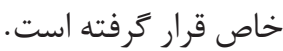
هدف: هدف از تحقيق حاضر، تعيين رابطه بين خلاقيت و هوش اجتماعى در بين دانشجويان دانشكاه علامه طباطبايى و شهيد بهشتى بوده است. مواد و روشها: جامعه آمارى اين يزوهش، كليهى دانشجويان دانشكده روانشناسى و علوم تربيتى دو دانشآه مورد مطالعه

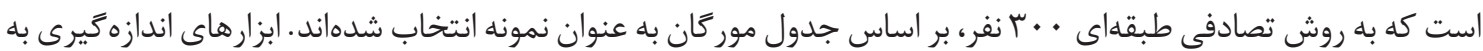
كار ترفته شده در اين تحقيق، يرسشنامهى استاندارد خلاقيت رندسيب و يرسشنامهى استاندارد هوش اجتماعى كرى است.

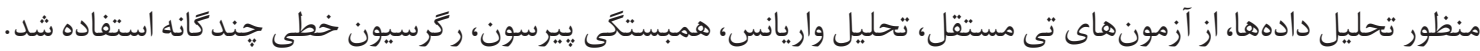
يافتها: نتايج حاكى از آن است كه بين مؤلفههاى خلاقيت و هوش اجتماعى تفاوت معنادارى وجود ندارد و نتايج تحليل واريانس نشان داده كه بين ميانكين خلاقيت دانشجويان به تفكيك مقطع تحصيلى تفاوت وجود دارد همجنين از بين إنى إنى

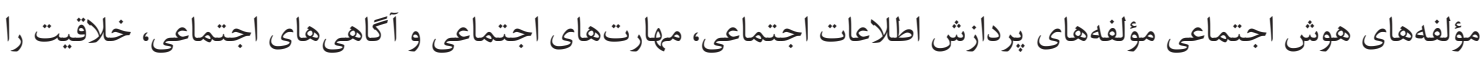
به طور معنادارى وييش بينى مى كنيند.

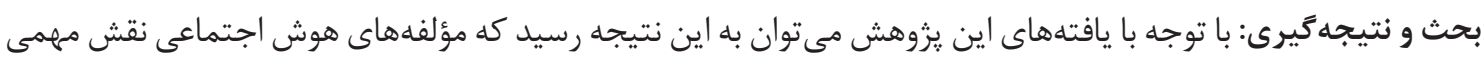

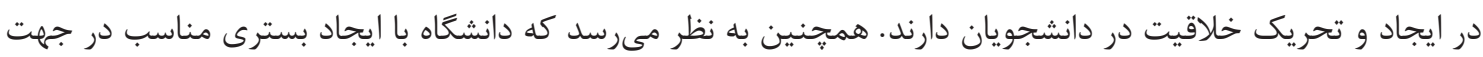

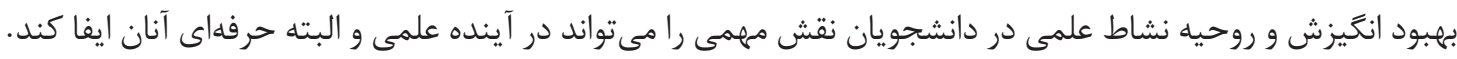

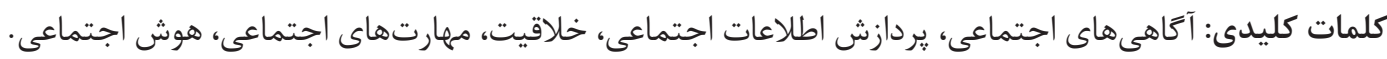

| تاريخ دريافت:

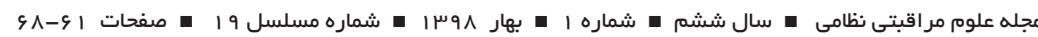

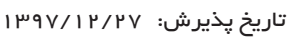

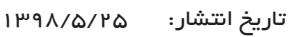

خردمندانه، روش هاى ارزيابى، سنجش هوش و تفاوتهاى بين فردى

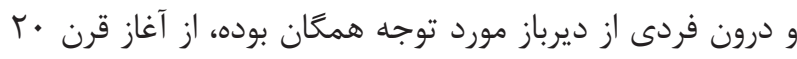

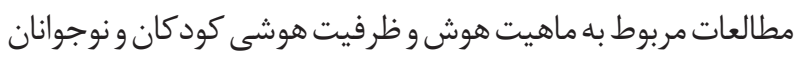
و بزر كسالان و بهرهَيرى از ابزارهاى كَوناكون براى ارزيابى ميزان
يكى از عوامل تأثير تزار بر دانشجويان و ييشرفت آنها عامل هوش است. در اين رهكذر توجه به ماهيت هوش خصوصاً (Intelligence)

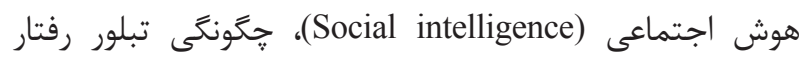


را به عنوان توانايى ضرورى براى افراد به منظور ارتباط، درك و

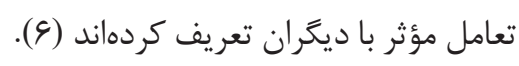
عوامل متعددى با هوش در ارتباطاند. ازجمله اين عوامل، مى توان به سن، جنسيت، محيط، ويزَّى هاى شخصيتى افراد و... اشاره كرد؛

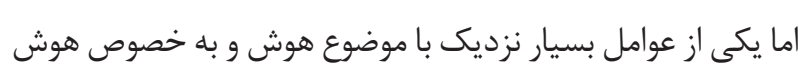

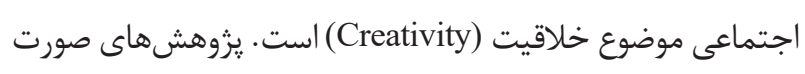

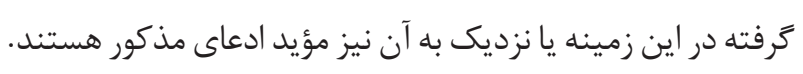

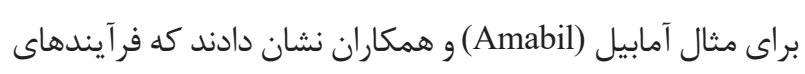

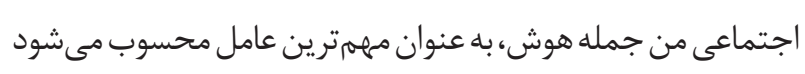

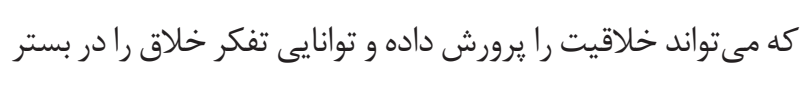

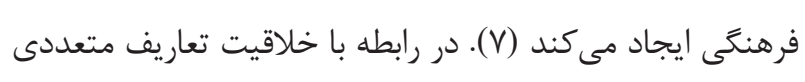

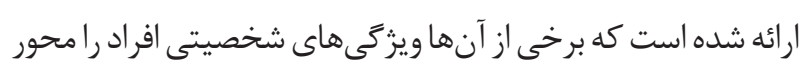

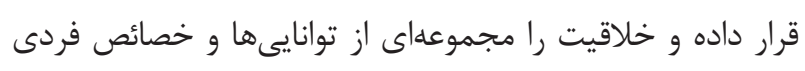

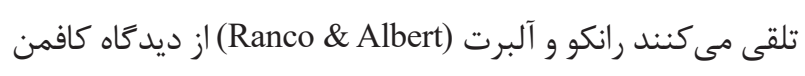
و استرنبرى (Kaufman \& Sternberg) خلاقيت همان يديدهاى است كه زندگى مدرن بشر متمدن را از زندگى ابتدايى نخستين

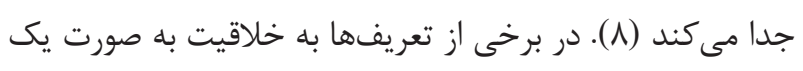

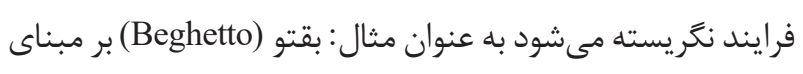

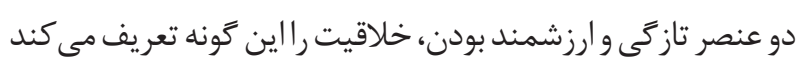

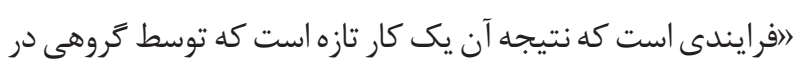

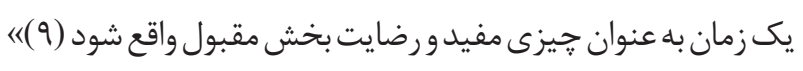

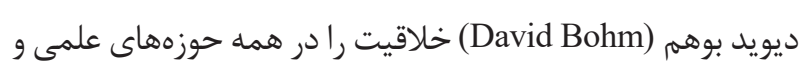
هنرى همسان مى يندارد و معتقد است روحيه هنرى به مثابه طلب

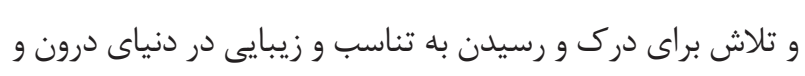
بيرون است، تشويق به خلاقيت نمى تواند موجب خلاقيت شود بلكه اين امر مستلزم فراهم ساختن زمينه مناسب از طريق سدها و موانع

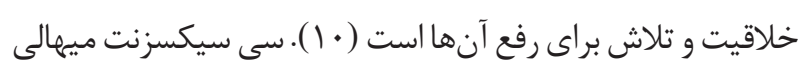
(Csikszentmihalyih)

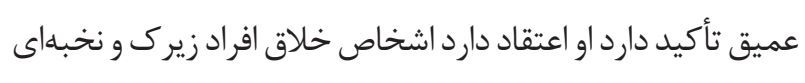
محسوب مى شوند كه به تحريك شناختى علاقهمندند، اين افر اددنيارا

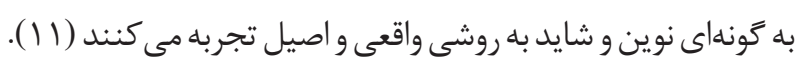

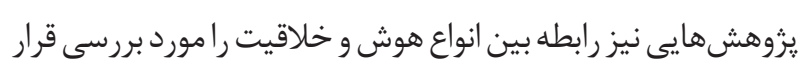
دادهاند كه به جند مورد اشاره مى كنيم، از جمله: نوفرستى به بررسى رابطه بين هوش هيجانى و خلاقيت در دانشجويان پرداخت، نتايج
هوش افراد در كشورهاى مختلف مورد توجه خاص قرار گرفته است. يكى از انواع هوش كه در اين :يزوهش نيز مد نظر است، هوش اجتماعى است. در همين راستا دانيل كلدمن (Daniel Goldman) از وازه هوش هيجانى (Emotional intelligence) صحبت به ميان آورده و آن را مؤثرترين ظرفيت براى موفقيت و شادمانى براى زندگى مىداند ( )، هوش هيجانى نام ديخر هوش بين فردى است

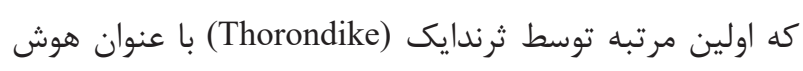
اجتماعى مطرح شد. لازم به ذكر است كه ثرندايك هوش را همانند اشترنبرگ در سه حيطه معرفى كرده و اصطلاح هوش اجتماعى، هوش انتزاعى (Abstract intelligence) و هوش عينى را به كار كرفت، هوش اجتماعى معرف ارتباطهاى بين فردى بوده و هوش أنتر عينى نشان دهنده تفكر در زمينه ملموسات است (؟). در حالى كه هوش انتزاعى خارج از ماده و ملموسات بوده و به شيوه تفكر حل

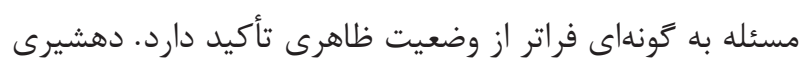
هوش اجتماعى را درى بهتر از روابط بين انسانها، احساسها، افكار و رفتارها تعريف كردهاند (r). مفهوم هوش اجتماعى به عنوان مجموعه صلاحيتهاى مهمم زندگى در نظر گرفته مىشود كه بخش مهرم زندگى انسان را به خود اختصاص داده است تونى بوزان (Tony Buzan) حلدمن اظهار دارد كه هوش بين فردى يا هوش اجتماعى يعنى مهارت عاطفى كه براى

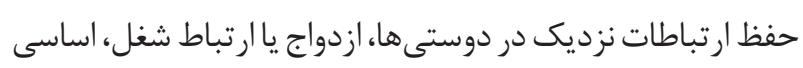
است. اين مهارت در كودكى شكل مي گيرد و در طول زندگى بروز مىيابد (Y). تعاريف ديخرى نيز از هوش اجتماعى مطرح است، از جمله: كارل آلبرت هوش اجتماعى راعبارت از خوب برخورد كردن با ديخران و به دست آوردن همكارى آنها مى داند و معتقد است

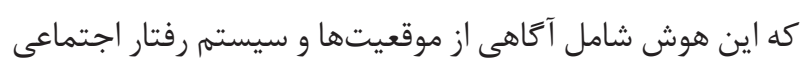
است كه آنها را كنترل مى كند و يك دانش از سبكهاى تعامل و استراترى است كه مىتواند به يك شخص در به انجام رساندن اهدافش در برخورد با ديكران كمك كند. كروان آن را به عنوان دو نوع هوش فردى كه به دو جنبه هوش درون فردى و هوش بين

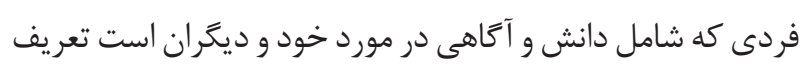
كرده است (ه). به نظر سلز هوش اجتماعى مى تواند به عنوان يكى نوع هوش كه در يشت تعاملات و رفتارها قرار دارد تعريف شود. دانخ، كوير و كلاسو (Dong, Koper \& Collaço) هوش اجتماعى 
ارتكاب يرخاشكرى و خشونت فيزيكى محافظت مى كند به اين معنى

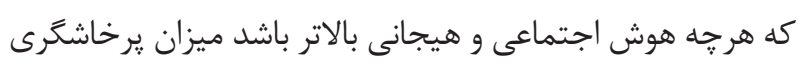

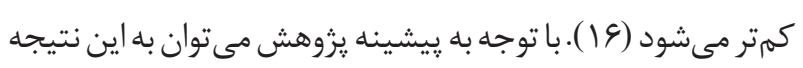

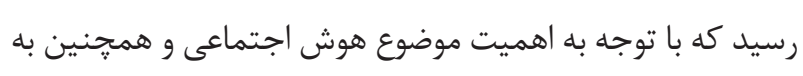

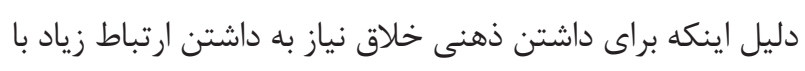

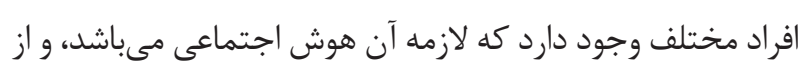

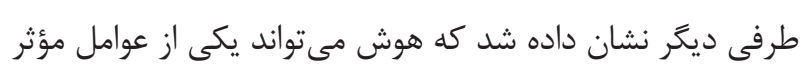

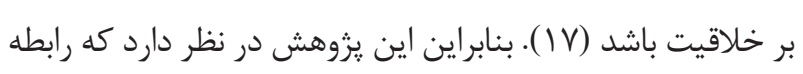

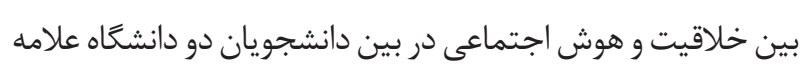

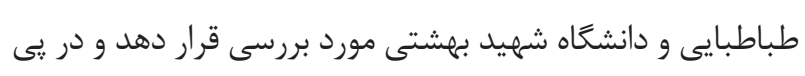

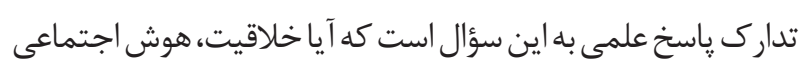

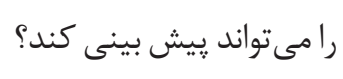

\section{مواد و روشها}

روش انجام يزوهش، توصيفى از نوع همبستخى است. جامعله آمارى

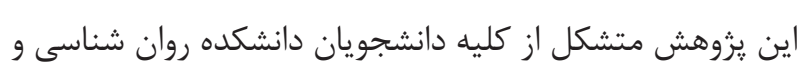

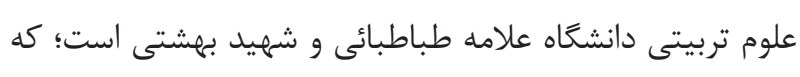

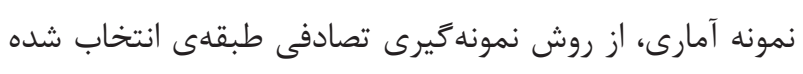

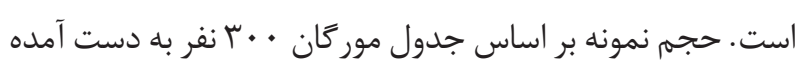

براى كردآورى دادهها از دو ابزار يرسشنامه استاندارد خلاقيت و

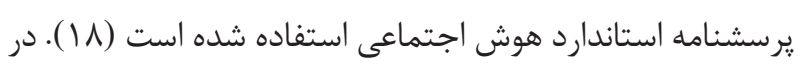

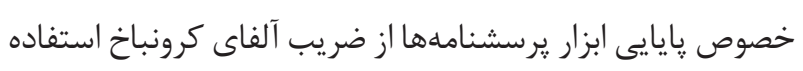

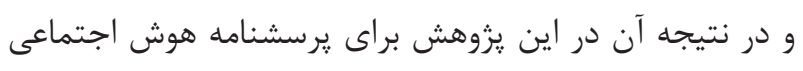

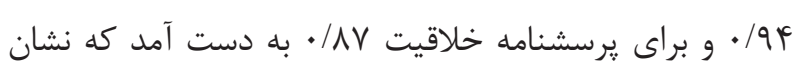

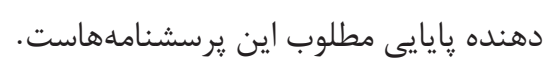

يافتهها در اين قسمت يافتههاى يزوهش در دو قسمت توصيفى و استنباطى مورد تجزيه و تحليل قرار مى گيرند.

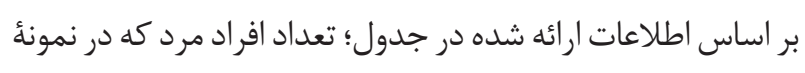

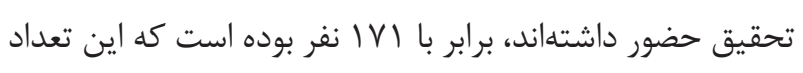

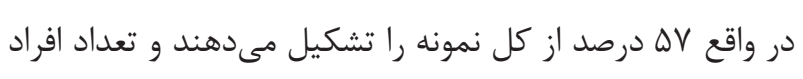

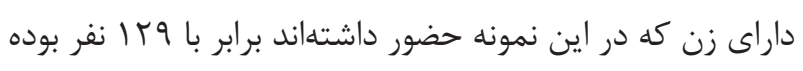

نشان داد كه بين مؤلفههاى مذكور در هر دو جنس رابطه مثبت و

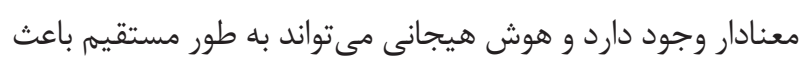

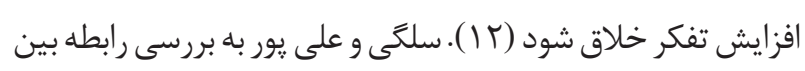
هوش اجتماعى و هوش هيجانى با دست برترى يرداختند و نتايج

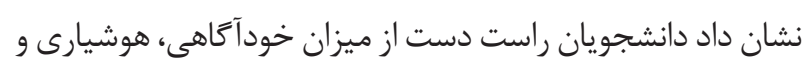

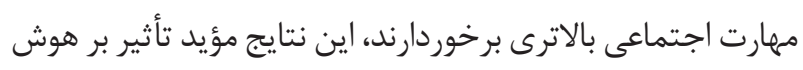

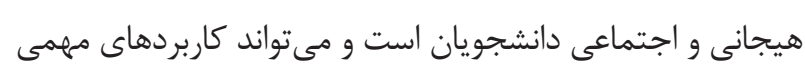

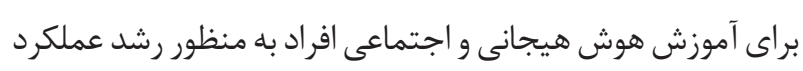

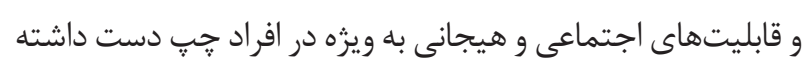

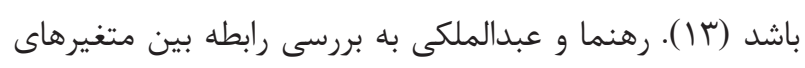
هوش هيجانى و خلاقيت با بيشرفت تحصيلى دانشجويان دانشعاه

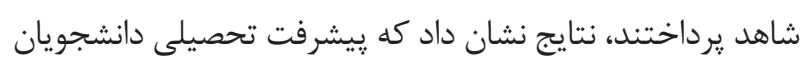

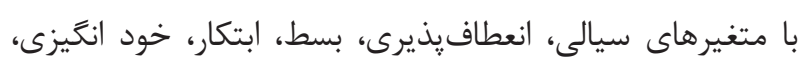

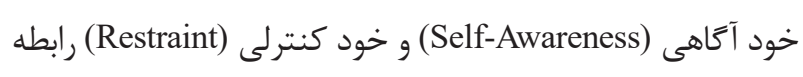
معنادارى دارند. بيشترين ميزان همبستكى در خصوص ييش بينى

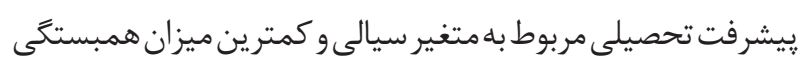

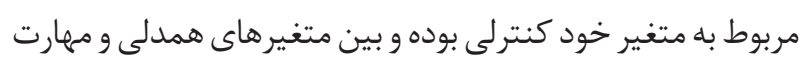

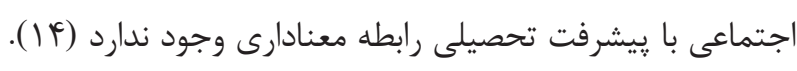

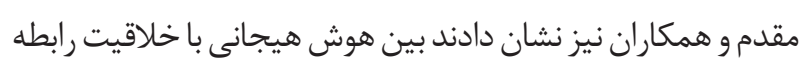

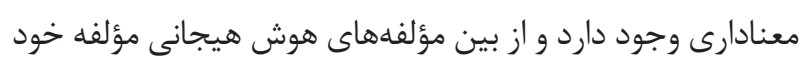

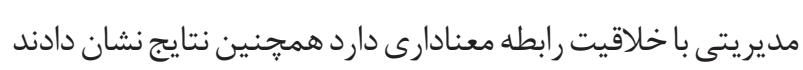

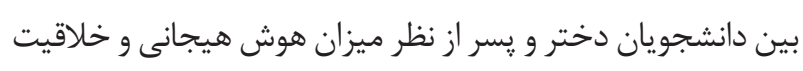

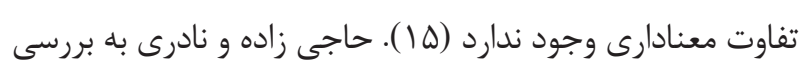
رابطه هوش اجتماعى با شادكامى و يرخاشكرى در دانشجويان

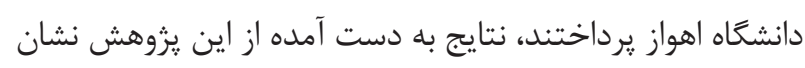

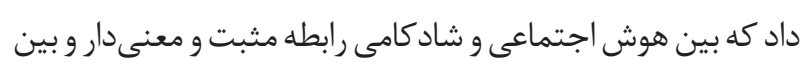

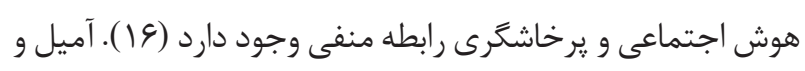

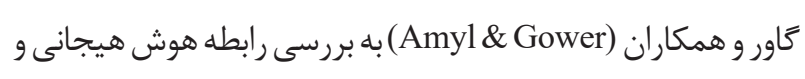

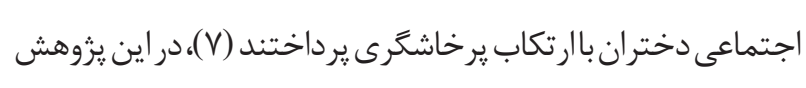

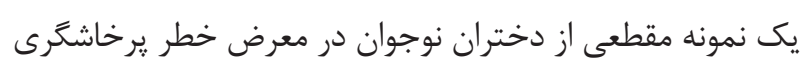

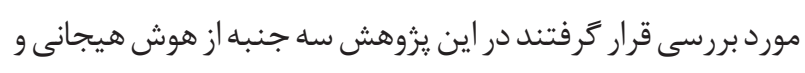

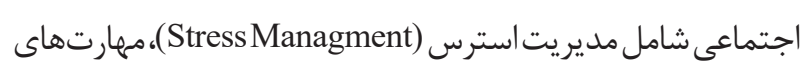
درون فردى و ميان فردى مورد مطالعه قرار گرفت ونتايج نشان داد كه هوش اجتماعى و هيجانى و مهارت هاى مديريت استرس دختر ان ران 


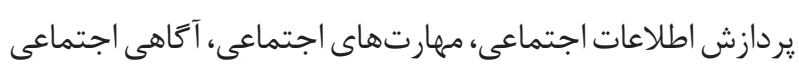

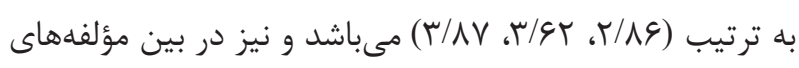

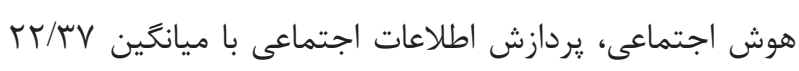

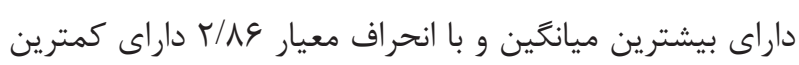

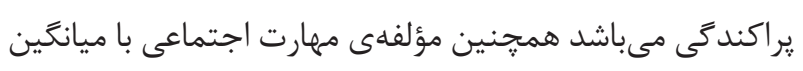

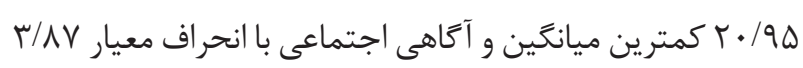

$$
\text { بيشترين يراكند آى را دارا است. }
$$

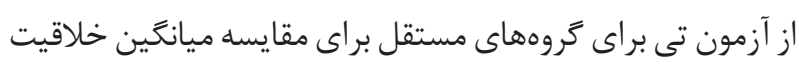

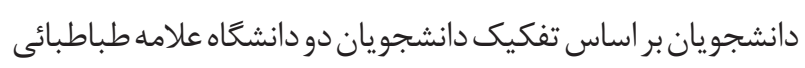

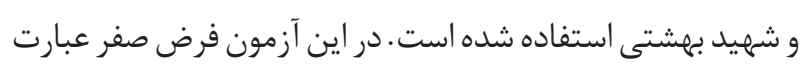

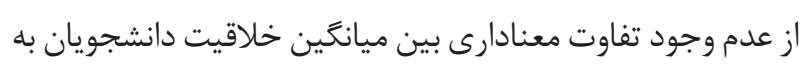

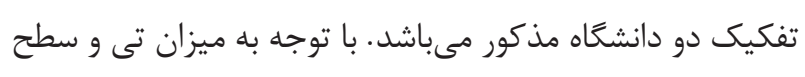

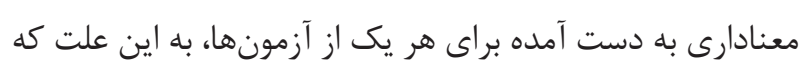
سطح معنادارى مربوط به دانشجويان به تفكيك دانشعاهها بيشتر

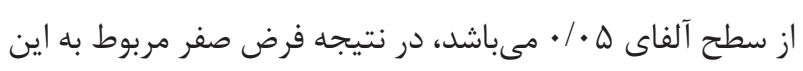

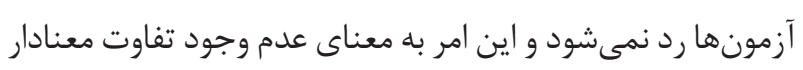
بين ميانگين خلاقيت دانشجويان به تفكيك دانشكاهها مى باشد. به منظور تجزيه و تحليل فرضيه جهارم مبنى بر مقايسه ميانگين

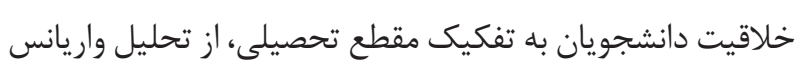
يكراهd استفاده شده است. در اين (Analysis of Variance) آزمونها فرض صفر عبارت از عدم وجود تفاوت معنادار بين ميانكين خلاقيت دانشجويان به تفكيك مقطع تحصيلى مىباشد و فرض أرضار

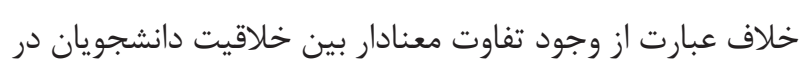

است كه اين تعداد به درصد از كل نمونه مىباشند.

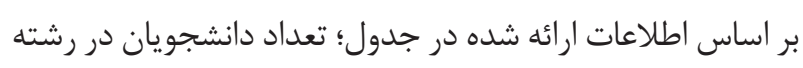
تحصيلى علوم تربيتى كه در نمونهُ تحقيق حضور داشتهاند، برابر

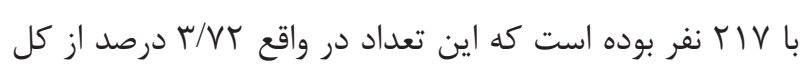
نمونه را تشكيل مى دهند و تعداد بم نفر از دانشجويان در رشته

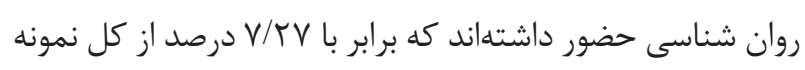
بوده است.

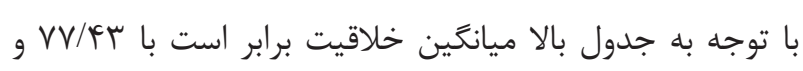

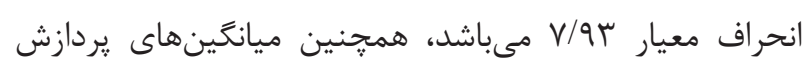

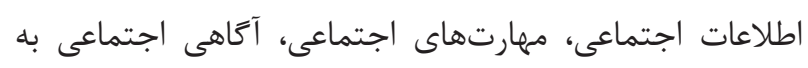

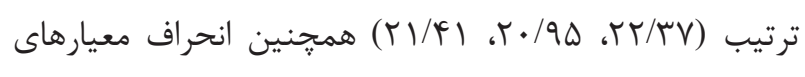

جدول ا- توزيع و درصد فراوانى نمونه مورد مطالعه به تفكيك جنسيت

\begin{tabular}{|c|c|c|}
\hline \multicolumn{2}{|c|}{ شاخص آمارى } & \multirow{2}{*}{ جنسيت } \\
\hline فروانى درصد & فروانى & \\
\hline$\cdot / \Delta V$ & $|V|$ & مرد \\
\hline . & 159 & زن \\
\hline$\cdot 11 \cdots$ & r.. & مجموع كل \\
\hline
\end{tabular}

جدول r- توزيع و درصد فراوانى نمونه مورد مطالعه برحسب رشته تحصيلى

\begin{tabular}{|c|c|c|}
\hline \multicolumn{2}{|c|}{ شاخص آمارى } & \multirow{2}{*}{ رشته تحصيلى } \\
\hline فروانى درصد & فروانى & \\
\hline$V T / r$ & rIV & علوم تربيتى \\
\hline$r V / V$ & N & روان شناسى \\
\hline$\cdot 11 \cdot$ & $r .$. & مجموع كل \\
\hline
\end{tabular}

جدول ب- ميانكَين و انحراف معيار خلاقيت و ابعاد هوش اجتماعى در دانشجويان دانشعاه علامه و بهشتى

\begin{tabular}{|c|c|c|c|c|c|}
\hline \multicolumn{5}{|c|}{ شاخص آمارى } & \multirow{2}{*}{ متغير } \\
\hline انحراف معيار & ميانغين & بيشينه & كمينه & تعداد & \\
\hline $\mathrm{V} / \mathrm{ar}$ & GF/VF & $\wedge \vee$ & f. & $r \cdot$. & خلاقيت \\
\hline$\Lambda \varepsilon / T$ & TT/TV & r. & ir & $r \cdot \cdot$ & يردازش اطلاعات اجتماعى \\
\hline GT/K & $r \cdot 190$ & 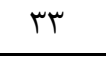 & 9 & $r \cdots$ & مهارتهاى اجتماعى \\
\hline H/AV & $|r| / F \mid$ & rt & ir & $r .$. & آكَاهى اجتماعى \\
\hline
\end{tabular}

جدول f- نتايج آزمون t به منظور بر رسى خلاقيت دانشجويان به تفكيك دانشعاهها

\begin{tabular}{|c|c|c|c|c|c|c|}
\hline سطح معنادارى & درجه آزادى & مقدار آماره & انحراف استاندارد & ميانگَين & كَروهها به تفكيك & متغير \\
\hline \multirow{2}{*}{.191} & \multirow{2}{*}{$\cdot / \Delta \mathrm{V}$} & \multirow{2}{*}{$1 / \cdot 1$} & $N / I V$ & sY/VF & علامه طباطبائى & \multirow{2}{*}{ خلاقيت } \\
\hline & & & $V / V$ & GY/VR & شهيد بهشتى & \\
\hline
\end{tabular}


جدول ه- نتايج آزمون تحليل واريانس يكراهه به منظور بررسى ميانكين خلاقيت به تفكيك مقطع تحصيلى

\begin{tabular}{|c|c|c|c|c|c|c|}
\hline سطح معنادارى & Fقدار F F & ميانگين مجموع مجذورات & درجه آزادى & مجموع مجذورات & منابع تغيير & متغير \\
\hline \multirow{3}{*}{$\cdot 1 \cdot r$} & \multirow{3}{*}{ r/99 } & VQ/TTG & $r$ & $F \Delta K / \Delta \Lambda$ & بين گروهها & \\
\hline & & \multirow{2}{*}{$91 / 11$} & rqV & $1 \wedge r G \cdot / 1 r$ & درون گروهها & خلاقيت \\
\hline & & & rq9 & INAIT/VY & كل & \\
\hline
\end{tabular}

كه بين هوش سازمان وخلاقيت، رابطه معنادارى وجود داشته است. به منظور تجزيه تحليل فرضيه دوم مبنى بر وجود رابطه بين

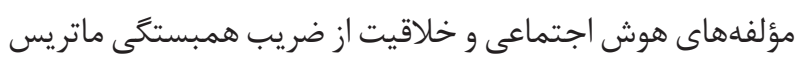
استفاده شده است. با توجه به جدول پايين و مشاهده ضرايب همبستخى و سطوح

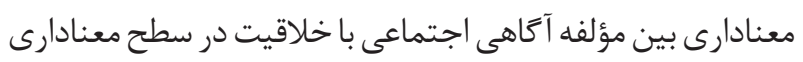

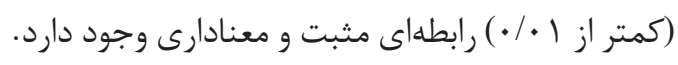

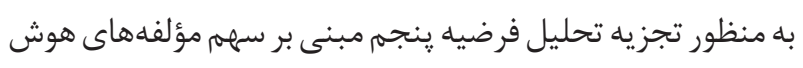

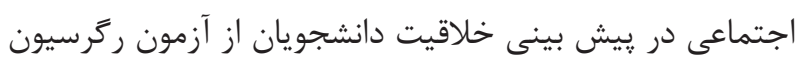
استفاده شده است.

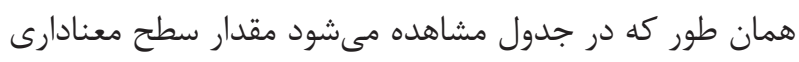

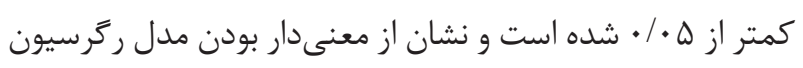
(Regression) بر متغير ملاك تأثير معنادار دارد.

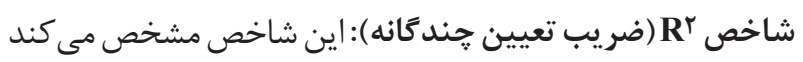
كه جند درصد از تغييرات متغير وابسته توسط متغيرهاى مستقل

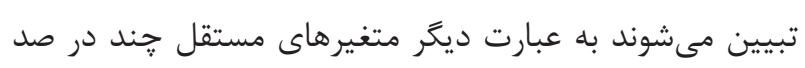

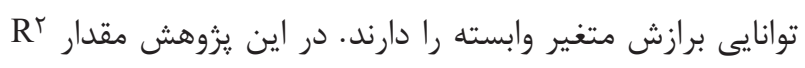

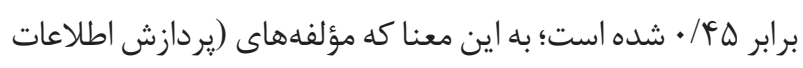

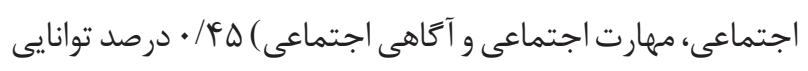

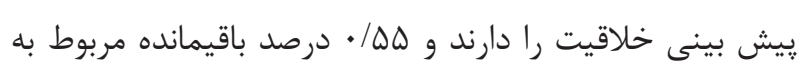
خطاى بيش بينى است.
جدول و- نتايج آزمون ضريب همبستكى بين هوش اجتماعى و خلاقيت

\begin{tabular}{|c|c|c|}
\hline \multicolumn{2}{|c|}{ شاخص آمارى } & \multirow{2}{*}{ متغير } \\
\hline سطح معنادارى & ضريب همبستخى & \\
\hline$\cdot 1 \cdot 1$ & $* * \cdot|\Delta|$ & خلاقيت اجتماعى \\
\hline
\end{tabular}

مقاطع تحصيلى مختلف مىباشد. با توجه به ميزان F و سطوح

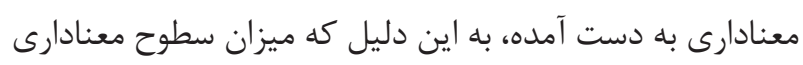

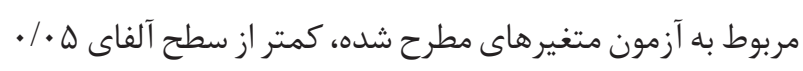

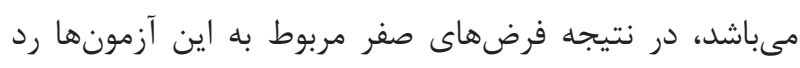
مىشود و اين بدين معناست كه بين ميانكَين خلاقيت دانشجويان

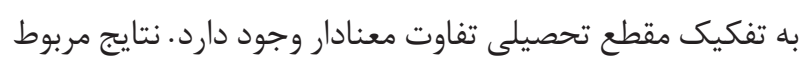

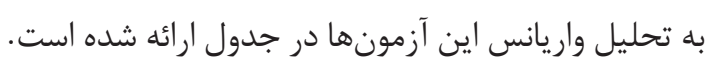
به منظور تجزيه و تحليل فرضيه اول مبنى بر اينكه ارابطه إندانه معنى دارى ميان هوش اجتماعى و خلاقيت در ارتباط با دانشجويان

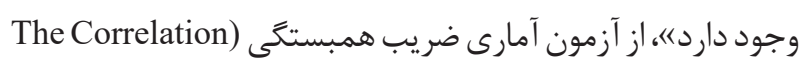
(Coefficient

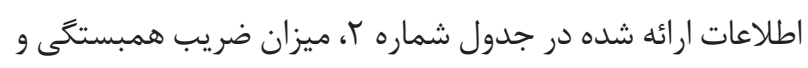

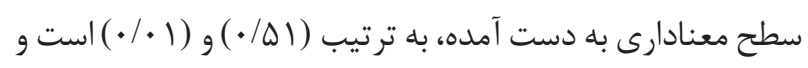
جون سطح معنادارى بيشتر از سطح آلفاى ه • • • است، در نتيجه

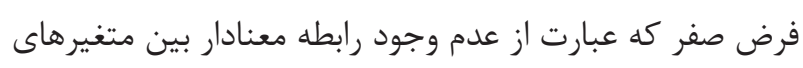

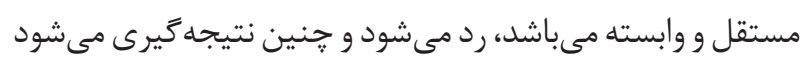
جدول V- نتايج آزمون ضرايب همبستكى بين مؤلفههاى هوش اجتماعى و خلاقيت

\begin{tabular}{|c|c|c|c|c|}
\hline خلاقيت & آكَاهى اجتماعى & مهارتهاى اجتماعى & يردازش اطلاعات اجتماعى & متغير \\
\hline$* * \cdot / V \cdot$ & $* * \cdot|\wedge|$ & $* * \cdot / \mathrm{VV}$ & 1 & يردازش اطلاعات اجتماعى \\
\hline$* * \cdot / / \Lambda$ & $* * \cdot / \mu q$ & 1 & $* * \cdot / V V$ & مهارتهاى اجتماعى \\
\hline$* * \cdot / 4 r$ & 1 & $* * \cdot / \uparrow q$ & $* * \cdot|\wedge|$ & آكاهى اجتماعى \\
\hline 1 & $* * \cdot /$ r & $* * \cdot / T \Lambda$ & $* * \cdot / V$ & خلاقيت \\
\hline
\end{tabular}


جدول ^- نتايج رَر سيون مؤلفههاى هوش اجتماعى بر خلاقيت

\begin{tabular}{|c|c|c|c|c|c|c|c|c|}
\hline Sig & $\mathbf{R}_{\text {adj }}^{r}$ & $\mathbf{R}^{r}$ & $\mathbf{R}$ & $\mathbf{F}$ & ميانغين مجذورات & درجه آزادى & مجموع مجذورات & مدل \\
\hline \multirow[t]{3}{*}{$\cdot 1 \cdot \cdot 1$} &.$|4|$ &.$/ 4 \Delta$ & $\cdot 10 \Lambda$ & $F T / T$. & GTVI/TY & r & $1 \Delta \Delta Y I / V T$ & رَرسيون \\
\hline & & & & & 1. & ras & rrar & باقيمانده \\
\hline & & & & & & rqq & INAIT/VT & كل \\
\hline
\end{tabular}

نكرديد و در نتيجه فرض صفر رد نمىشود و اين به معناى عدم وجود تفاوت معنادار بين ميانگين خلاقيت دانشجويان به تفكيك رك دانشعاه مىباشد. اين مىتواند بيانغر اين موضوع باشد دانشجويان دو دانشعاه از بعد خلاقيت در سطح يكسانى قرار دارند. نتايج حاصل از فرضيه جهارم مبنى بر وجود تفاوت در خلاقيت ميان دانشجويان به تفكيك مقطع تحصيلى تائيد گرديده است در اين آزمون فرض صفر عبارت از عدم وجود تفاوت معنادار بين ميانگين خلاقيت دانشجويان به تفكيك مقطع تحصيلى مىباشد در نتيجه فرض صفر رد مىشود و اين بدين معناست كه بين ميانگين خلاقيت دانشجويان به تفكيك مقطع تحصيلى تفاوت معنادار وجود دارد كه نتايج اين يروهش با يافتههاى اعظم مقدم و همكاران مبنى بر وجود تفاوت معنادار بين ميانخين نمرههاى دانشجويان از نظر مقطع تحصيلى، همسو مىباشد (·r). در عين حال با يافتههاى هيوود مبنى بر عدم وجود تفاوت معنادار بين ميانخين نمرههاى دانشجويان در خلاقيت از نظر مقطع تحصيلى، همسو نمىباشد (Y).

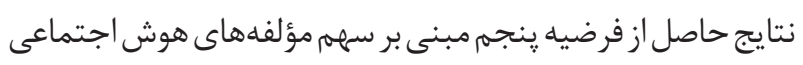
در ريش بينى خلاقيت دانشجويان نشان مىدهد كه مؤلفهاى يردازش اطلاعات اجتماعى، مهارت اجتماعى و آتاهى اجتماعى

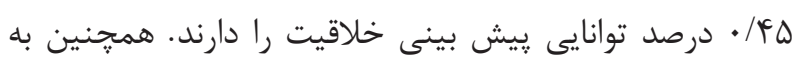
منظور بررسى اينكه كدام متغيرها تأثير معنادارى در مدل دارند

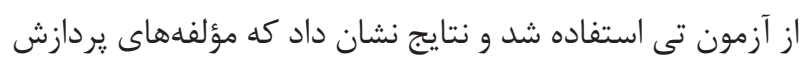
اجتماعى، مهارت اجتماعى و آكاهى اجتماعى در سطح يك درصد تأثير معنادارى دارند و مثبت بودن اين سه ضريب در واقع نشان دهنده اين است با افزايش اين مؤلفهها ميزان خلاقيت نيز افزايش

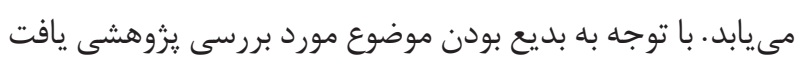

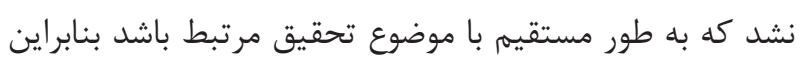
به مقايسه نتايج اين فرضيه با فرضيههاى مشابه مىيردازيم، در تحقيقى كه رضايى و خليلزاده انجام داده نتايج نشان مى دهد كه
شاخص R r adj (ضريب تعيين تصحيح شده): اين شاخص توانايى "يش بينى متغير وابسته را توسط متغيرهاى مستقل در جامعه راتئ بررسى مى كند در واقع با كمى تعديل، نمونه را به تمام جامعه بسط مى دهد. مقدار اين ضريب در اين يروهش أ| • • شده است، به عبارت ديخر، مؤلفههاى يردازش اطلاعات اجتماعى، مهارت اجتماعى و آكاهى اجتماعى ||c/ • درصد توانايى پيش بينى خلاقيت را دارند.

\section{بحث و نتيجهذ}

هدف اين يزوهش بررسى رابطه بين خلاقيت و هوش اجتماعى در دانشجويان دانشكده روان شناسى و علوم تربيتى دانشعاههاى علامه طباطبايى و شهيد بهشتى است بوده است. نتايج حاصل از آزمون فرضيه اول مبنى بر وجود رابطه مثبت و و معنادارى بين هوش اجتماعى و خلاقيت مىباشد هـ • / P اين به إسه اين معنى است كه با بالا رفتن هوش اجتماعى، خلاقيت دانشجويان نيز بالا مىرود. با توجه به اينكه مفهوم هوش اجتماعى يك سازه نسبتاً جديد روانشناختى است و يزوهشهاى انجام شده در اين زمينه بسيار محدود است، يثوهشى يافت نشد كه به طور مستقيم به بررسى رابطه هوش اجتماعى و خلاقيت بيردازد؛ يافتههاى بدست آمده از اين يزوهش با يافته هاى نوفرستى (1 ا (1)، آميل كاور

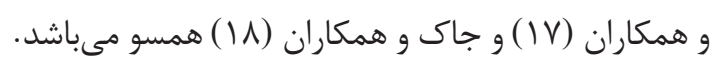
همجنين نتايج حاصل از فرضيه دوم مبنى بر رابطه بين مؤلفه هاى هوش اجتماعى و خلاقيت تائيد گرديد (ه •/P> P) و اين نشان مى دهد كه بين مؤلفههاى هوش اجتماعى (يردازش اطلاعات اجتماعى، مهارتهاى اجتماعى و آكَاهىهاى اجتماعى) با خلاقيت رابطه معنادارى وجود دارد. نتايج اين بزوهش با يافتههاى بشارت (19) مبنى بر وجود رابطه ميان مؤلفههاى هوش هيجانى به خصوص خود مديريتى با خلاقيت، همسو مىباشد؛ اما با توجه

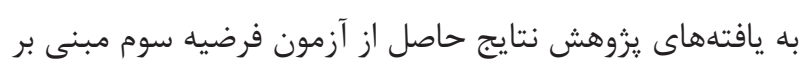
وجود تفاوت خلاقيت ميان دانشجويان به تفكيك دانشعاه تائيد 


$$
\begin{aligned}
& \text { تشكر و قدردانى } \\
& \text { از يرسنل و دانشجويان محترم دانشگاههاى علامه طباطبايى و } \\
& \text { شهيد بهشتى كه در اجراى اين يزوهش ما را يارى كردند، تشكر }
\end{aligned}
$$

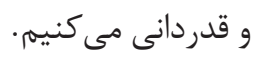

$$
\begin{aligned}
& \text { تضاد منافع }
\end{aligned}
$$

\section{References}

1- Goldman, D. Social intelligence. The new science of human relationships. Random house. New York:Bantam, 2007.

2- Thorndike EL. A constant error in psychological ratings. J Applied Psychology. 1920;4(1):25-9.

3- Dehshiri, Gh.. Normalization of its EQ-I questionnaire for evaluationDifferent aspects of intelligence in students in Tehran universities. thesisMaster of Psychology, Department of Psychology and Educational Sciences, Allameh University Tabatabai Tehran. 2003.

4- Tony Buzan P. Social intelligence, t HarperCollins Publishers, Inc. Plate section illustrations by Alan Burto. 2002.

5- Crowne KA. The relationships among social intelligence, emotional intelligence and cultural intelligence. Organization Management J. 2009;6(3):148-63.

6- Dong O, Koper R.G, Collaço C.M. Social Intelligence, Selfesteem, and Intercultural Communication Sensitivity, Intercultural Communication Studies. XVII (2), 2008:162-165.

7- Amabile TM, Schatzel EA, Moneta GB, Kramer SJ. Leader behaviors and the work environment for creativity: Perceived leader support. The Leadership Quarterly. 2004;15(1):5-32.

8- Kaufman JC, Sternberg RJ. The Cambridge handbook of creativity. New york: Cambridge University Press; 2010.

9- Beghetto RA. Creativity in the classroom. New York: Cambridge University Press; 2010. 447-63 p.

10- Bohm D, Peat FD. Science, order and creativity: Routledge; 2010.

11- Csikszentmihalyi, M. Implications of a system perspective for the study of creativity. In r.j. sternberg(eds). Handbook of creativity, new york: cambridge university press. 2009.

12- Nofresti A. Emotional intelligence leads to creative thinking. Quarterly J Transformational Psychology, Iranian psychologists. 2012;7(26):175-89.

13- Solgi Z, Alipour A. Comparison of social intelligence and

$$
\begin{aligned}
& \text { يردازش اطلاعات اجتماعى بهترين ييش بين براى رضايت شغلى }
\end{aligned}
$$

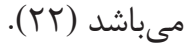

$$
\begin{aligned}
& \text { با توجه به نتايج اين يزوهش مبنى بر اينكه با بالا رفتن هوش } \\
& \text { اجتماعى خلاقيت افراد نيز بالا مىرود يِيشنهاد مىشود كه } \\
& \text { دانشخاهها تلاش بيشترى در بالا بردن هوش اجتماعى افراد داشته } \\
& \text { باشد و طراحى برنامههاى درسى دانشخاه بيشتر به شكل گروهى } \\
& \text { و با همكارى صورت كيرد كه خود به بالا رفتن هوش اجتماعى } \\
& \text { افراد كمك مى كند و در نتيجه خلاقيت بالا مىرود و اين خود به } \\
& \text { ييشرفت جوامع كمك بسيارى مى كند. }
\end{aligned}
$$

emotional intelligence of students considering their superiority. Quarterly J Applied Psychology. 2012;6(24):170-84.

14- Rahnama A, Maliki J. Relationship between emotional intelligence and creativity variables with academic achievement of students of shahed university. New educational thoughts. 2009;5(2):107-23.

15- Moghaddam, A, Nikbakht, A, Nikan, Sh., \& Siadat, S. A. (2008). Investigating the relationship between Emotional Intelligence with Student Creativity, Journal of Educational Psychology Studies, 2008:5(1):112-99.

16- Hajizadeh M. Validation of social intelligence scale and its relationship with happiness and aggression among students of ahvaz islamic azad university. Msc master's degree in general psychology. 2008.

17- Amyl Gower, A. Brief report: associations between girls socialemotional intelligence and perpetration. Jurnal of adolescence. 2014;(37)1

18- Jauk, E, benedek, M, dunst, B, neubauer, A,C. The relationship between intelligence and creativity: new support for the threshold hypothesis by means of empirical breakpoint detection. Intelligence. 2013;41(212-221).

19- Besharat M.A. Investigating the Relationship between Personality and Emotional Intelligence. Educational Journal and Psychology. University of Tehran.2007:8(2):94-79.

20- Azam Moghaddam, A, Nikbakht A. The relationship between emotional intelligence and student creativity. 2008;5(1):38-59.

21- Heywood, J.Engineering education research and development in curriculum and instruction. New york: wiley interscience press. 2005.

22- Rezaei A. Khalilzadeh A. The Relationship between Social Intelligence of Principals and Job Satisfaction of School Teachers. Journal of Educational Sciences. 2(7):145-121. 